\title{
Managing human pressures to restore ecosystem health of zanzibar coastal waters
}

\begin{abstract}
The health and functioning of coastal ecosystems around Zanzibar Islands is severely affected by a combination of human and natural pressures. These consists of rapid population growth, uncontrolled tourism, overfishing and destructive fishing practices, harvesting of mangroves, dumping of solid waste and untreated wastewater from urban areas, acting on top of climate change related increases in sea temperatures, and sea levels as well as outbreaks of invasive species. Despite a high financial value of the coastal zone related to tourism, fisheries and seaweed production, documentation of the environmental degradation is scarce and clear environmental targets are missing. Through a combination of baseline studies and a literature review, we give an overview of how human and natural pressures have affected the coastal ecosystem health of Zanzibar. We give examples of how well managed marine protected areas can mitigate degradation of coral reefs, and provide suggestions for steps needed to improve management of coastal marine resources.
\end{abstract}

Keywords: zanzibar, coastal waters, ecosystem health, pollution, over exploitation, recovery, monitoring
Research Article

Volume 7 Issue 2 - 2018

\author{
Peter A Staehr,' Mohammed Sheikh, ${ }^{2}$ Rashid \\ Rashid, ${ }^{2}$ Ali Ussi, ${ }^{2}$ Mohammed Suleiman, ${ }^{2}$ \\ Ulrike Kloiber,' Karsten Dahl,' Zhanna \\ Tairova, ${ }^{4}$ Jakob Strand,' Baraka Kuguru, ${ }^{5}$ \\ Christopher Muhando 6 \\ 'Department of Bioscience, Aarhus University, Denmark \\ ${ }^{2}$ Tropical Research Center for Oceanography, State University \\ of Zanzibar, Tanzania \\ ${ }^{3}$ Chumbe Island Coral Park (CHICOP), Tanzania \\ ${ }^{4}$ Section for Aquatic Biology and Toxicology, Department of \\ Biosciences, University of Oslo, Norway \\ ${ }^{5}$ Tanzania Fisheries Research Institute (TAFIRI), Tanzania \\ ${ }^{6}$ Institute of Marine Sciences (IMS), University of Dares Salaam, \\ Tanzania
}

Correspondence: Peter A Staehr, Section for marine biodiversity and experimental ecology, Department of Bioscience, Aarhus University, Denmark, Email pst@bios.au.dk

Received: February 09, 2018 | Published: March 01, 2018

\section{Introduction}

Zanzibar is a small $\left(2461 \mathrm{~km}^{2}\right)$, densely populated (530 people per $\mathrm{km}^{2}$ ) archipelago, approximately $30 \mathrm{~km}$ off the coast of Tanzania. The coastal zone of the Zanzibar archipelago is rich in natural resources and consists of diverse ecosystems including coral reefs, mangroves, seagrass beds, beaches, dunes, estuaries, rocky shores and coastal forests. ${ }^{1}$ Coral reefs include fringing reefs, which occur as a continuous band off the coasts and patchy reefs mostly found in the channels surrounding Zanzibar. The fringing reef has a reef crest which acts as a wave break, dissipating most of the wave energy thus protecting the back-reef lagoons and the beach where seaweeds are cultivated. Coral reefs are associated with highly diverse assemblages of fishes and are estimated to support up to $70 \%$ of the artisanal fisheries conducted in Zanzibar waters, ${ }^{2}$ providing an income to about $20 \%$ of the Zanzibar population $^{3}$ and an important local protein supply. Seagrasses around Zanzibar dominate on soft bottoms in the shallow waters of back-reef lagoons, estuaries and intertidal areas. Seagrass beds support valuable fishery resources, including prawns and finfish and provide feeding grounds for turtles.

The sea is an important resource for Zanzibar and a fundamental part of the nature and environment of the archipelago. The people of Zanzibar are closely related to the sea, both as a source of income and leisure, but also for the cultural heritage of the local people ${ }^{4}$ making the ecosystem services provided by the coastal environment significant to Zanzibar. ${ }^{5}$ Of the archipelago's population most $(0.9$ million) live on Unguja Island. ${ }^{6}$ The average per capita gross domestic product (GDP) was only 935 US dollars in $2014^{7}$ and roughly $30 \%$ of the population falls below the basic needs poverty line, most of which lives in the rural regions. ${ }^{6}$ The archipelago is highly dependent on its marine resources, which in 2008 accounted for approximately $30 \%$ of GDP, 77\% of annual investments in Zanzibar and a large foreign exchange and employment. ${ }^{5}$

However, despite its clear economic importance, the marine coastal ecosystem of the Zanzibar archipelago has been seriously degraded due to mostly human causes. These include uncontrolled tourism development, rapid coastal population growth, overfishing and destructive fishing practices, overharvesting of limited forest resources, especially the mangroves, and discharge of untreated solid and liquid water from urban areas containing nutrients and hazardous substances. ${ }^{8,9}$ Furthermore, natural stressors such as periodic coral bleaching by heat waves during El Niño years and out breaks of invasive species such as the crown-of-thorns starfish (Acanthaster planci) puts severe pressure on the health of the marine environment. ${ }^{10}$

Given the high dependency of Zanzibar on the marine resources, it is very important to establish a balance between human exploitation of the sea and the ability of the sea to absorb these pressures. A longterm balance and a reduction in local conflicts over access and use of marine resources are needed in order to allow future generations of Zanzibar is to enjoy and benefit from the rich seas surrounding their Island. ${ }^{4} \mathrm{~A}$ first important step towards establishing such a sustainable balance between human exploitation (pressures) and carrying 
capacity is to investigate how these pressures and environmental responses have changed over time. This study is a first step towards a baseline analysis of long-term changes in human pressures and related responses of the marine environment of Zanzibar. We provide an updated documentation on changes in a number of important press factors, and evaluate whether these conditions have affected different key components of the marine ecosystem health. We highlight a series of scientific and management actions required for the longer-term benefit of the Zanzibar population with relevance to other coastal regions with similar problems.

\section{Materials and methods}

\section{Study site}

Zanzibar is located in the Western Indian Ocean $\left(39^{\circ} 05^{\prime} \mathrm{E}\right.$ to $39^{\circ}$ $55^{\prime} \mathrm{E}$ and $4^{\circ} 45^{\prime} \mathrm{S}$ to $6^{\circ} 30^{\prime} \mathrm{S}$ ) ca. $30 \mathrm{~km}$ off the East African Coast. As a semi-autonomous State of the United Republic of Tanzania, Zanzibar consists of two main islands, Unguja, which is commonly referred to as Zanzibar as most people live here and because of Zanzibar city, and Pemba, as well as several smaller islands. The coastline around Unguja and Pemba is characterized by alternating regimes of sandy beaches and rocky outcrops with fringing coral reefs, and large estuarine areas with dense seagrass meadow and extensive mangroves forests. ${ }^{1,11}$ Unguja is the Island where most data on water quality and coastal ecosystem health has been gathered, and our study therefore focuses on the southern Island Unguja.

Zanzibar has a tropical climate with annual rainfall of on average $1600 \mathrm{~mm}$ and $1900 \mathrm{~mm}$ for Zanzibar and Pemba, respectively, and air temperatures ranging between 29 and $32^{\circ} \mathrm{C}$ on average. Water movement around Zanzibar Islands are determined by a combination of the East African coastal current, which originates from the South Equatorial Current of the western Indian Ocean, and local currents largely influenced by the Monsoon wind system, and the diurnal tides which varies between -0.2 and $4.5 \mathrm{~ms}^{-1} .{ }^{12}$ The long rainy season typically occurring from March to May defines the slightly stronger (winds of around $2 \mathrm{~ms}^{-1}$ ) South Easterly monsoon (SE), while the weaker (winds below $1 \mathrm{~ms}^{-1}$ ) North Easterly (NE) monsoon occurs during the shorter, less rainy season from September to November. ${ }^{13,14}$

\section{Data sources}

Data presented in this study derive from multiple sources including previously published data, regional statistics and newly collected unpublished data. Four main categories of data and information are presented: 1) Historical changes in anthropogenic pressures based on previously published data and publicly available statistics; 2) Contemporary data on the health of the coastal ecosystems and water quality based on new data from a baseline study; 3) Data on coral reef health based on published and new data obtained from a long-term coral reef monitoring program; 4) Recent reports on management of threats and pressures to coastal habitats of Zanzibar. This category includes unpublished data from a marine protected area and insights from active engagement with key stakeholders on Zanzibar.

\section{Historical changes in anthropogenic pressures}

Anthropogenic pressures are considered those, which are either directly or indirectly related to human activities. For the historical long-term analysis, we have been able to include data on human population growth, increases in the number of tourists, increases in seawater temperature and sea level rise, caused by human induced climate changes, and finally, changes in fishing pressure measured by the annual fish landings. Data on human population growth and tourism was obtained from the Tanzania Population census data and the Tourism Commission of Zanzibar. Sea surface temperature (SST) data was compiled from Mc Clanahan et al., ${ }^{12-14}$ using satellite derived data (1951 to 2002) and temperature logger data collected by the Institute of Marine Sciences. In the period between 2009 to 2014, a comparison was made between satellite derived SST logger data, showing a fine agreement (Kuguru, personal communication; $\left.\mathrm{r}^{2}=0.85, \mathrm{p}<0.001\right)$. Data on sea level rise was obtained from a tide gauge station ID (no 1600), located in Stone Town harbor. To evaluate longer-term changes, we have chosen to normalize sea level to the average of the measurement period (1984 to 2014).

\section{Evidence of environmental impacts from baseline studies}

Longer-term records of solid and dissolved waste do not exist for the coastal waters of Zanzibar. To provide some estimates on the human impact on the coastal marine environment associated with waste, a series of baseline studies were initiated in 2015. These included marine litter, microplastic, hazardous substances used as antifouling (Tributyltin, TBT, and Irgarol-1015), and metabolites of polycyclic aromatic hydrocarbons (PAHs) in fish bile. In addition, inorganic nutrients, phytoplankton biomass (chlorophyll a, Chla) and fecal coliform bacteria were measured in the waters around Unguja Island.

Marine litter (solid waste) was quantified along $100 \mathrm{~m}$ beach stretches around Unguja Island using the UNEP/IOC guideline monitoring of beach litter. ${ }^{15}$ Microplastic sampling was performed at the same beaches by collecting subsamples in the upper part of the tidal zone from 3 replicate areas each of $20 \mathrm{~cm}^{2}$ along a $100 \mathrm{~m}$ stretch of the beach. Water sampling for nutrients, Chla, and coliform fecal bacteria was done at several near shore sites around Unguja Island during late May 2015, following standard sampling procedures and laboratory analysis. ${ }^{16}$ However, this study only summarizes the collected pollution data in order to provide an insight into the contemporary levels of exposure. In regards to the contaminant studies, bivalve and gastropod species were sampled in the tidal zone for analyses of TBT levels and TBT specific effects in form of the impose phenomena ${ }^{17}$ at several near shore sites around Stone Town on the west coast of Unguja Island. Preferably, the benthic goby fish (Periophthalmus sobrinus) was sampled for analyses of biliary levels of PAH-metabolites according to the procedure described in. ${ }^{18}$ To the extent possible, we compare the observed levels with previous findings.

\section{Monitoring of benthic habitats}

\section{Evidence from long term coral reef monitoring}

Coral reef monitoring has been conducted since the early 90 's by using the Line Intercept Transect method by English et al., ${ }^{19}$ with 6-12 replicates per site in selected years. ${ }^{20}$ Data were collected along a $20 \mathrm{~m}$ long transect by skilled divers who recorded the proportions of reef benthos (live coral cover, coralline algae, soft corals, sponges, fleshy algae and non-biotic cover). Macro-invertebrates (lobsters, clams, 
gastropods, sea urchins, sea cucumbers, sea stars, crown-of-thornsstarfish) were counted in $20 \mathrm{mx} 1 \mathrm{~m}$ belt transects. Initially, live hard corals were recorded and grouped as 'Acropora' and 'Non-Acropora' species. However, from year 2009 onward the sampling methodology has been improved by recording live coral species at generic level, which resulted into recording more species than before, though it is possible to aggregate recent data to the same level as previous collected data. The monitoring has taken place mostly during intermonsoon periods when the sea was calmer.

\section{Seagrasses and mangroves}

Systematic monitoring of the density and areal extent of seagrasses and mangroves in Zanzibar waters has not been conducted. Based on interviews and recent monitoring in selected areas, we provide an overall assessment of the historical changes, which have occurred.

\section{Managing threats and pressures}

\section{Chumbe reef sanctuary}

The Chumbe Reef Sanctuary (CRS) is a 55.06 ha No-Take-Area (NTA) on the western side of Chumbe Island which is privately managed by Chumbe Island Coral Park (CHICOP). Fishing and extractive resource uses have been prohibited in the CRS since 1994. ${ }^{21}$

\section{Coral reef bleaching studies}

Sea surface temperatures inside the CRS have been recorded daily since 1997 using in situ water temperature data loggers. This is done in collaboration with the Institute of Marine Sciences (IMS) at the University of Dar es Salaam. Parallel to this, a coral reef monitoring program was established to assess coral reef health and associated changes. Here we show monitoring data on effects of the 2016 El Nino coral-bleaching event. Benthic cover was quantified in 41 frames of $50 \mathrm{~cm} \times 50 \mathrm{~cm}$ based photo quadrats, taken by snorkeling and randomly placed along the reef crest at a water maximum depth of $3 \mathrm{~m}$.

\section{Removal of invasive species}

The most threatening invasive species in coral reefs are Crownof-Thorns Starfish (COTS). In Zanzibar COTS outbreaks were rarely observed prior to 1990's and were first documented in Pange reef in 1988. The IMS coral reef monitoring program reported an increase of COTS outbreak incidences from the year 2002, which then severely reoccurred in 2004-2006 in reefs of Bawe, Pange, Nyange, Murogo, Chumbe, Mnemba, Tumbatu and Nungwi. In 2004, Chumbe Island Coral Park (CHICOP) responded to this threat with a well managed and documented COTS removal program.

\section{Protection against overexploitation of fish}

CHICOP has established a coral reef monitoring program in 2006, specifically designed to provide evidence of management effectiveness of the strict Chumbe NTA. Among other factors, the program monitors densities and sizes of six commercial fish families in comparison to an unprotected control reef outside the CRS.

\section{Stakeholder Engagement}

The State University of Zanzibar (SUZA) organized a two-day stakeholder workshop where marine scientists from SUZA presented their work and knowledge on pressures and problems, according to insights gained from the baseline studies. Experiences with using marine monitoring programs to improve management of marine resources were also presented by project partners from Denmark. Following this, group discussions were initiated to identify knowledge gaps and needed actions. This involved representatives of other local research institutions on the Island.

\section{Results and discussions}

\section{Historical changes in anthropogenic pressures}

\section{Growth in human population, tourism, fisheries and energy} demand

The Island has experienced an exponential growth in the native human population, rising from 354,815 in 1967 to a staggering $1,303,569$ in 2014(Tanzania Population census). This amounts to a population density of 530 inhabitants per $\mathrm{km}^{2}$ making Zanzibar one of the top three densely populated countries in Africa. From the 1990's, the liberalization of the Tanzanian economy has opened coasts and beaches for tourism investments, causing an exponential increase in the annual number of visiting tourists rising 16 fold, from 19,368 to 311,891 annual visitors from 1985 to 2014 (Tanzania Population census). As tourists have a substantially higher coastal, marine and freshwater resource demand than indigenous people on the Islands ${ }^{22}$ this significant raise suggests a significant pressure on the natural resources including coastal marine habitats.

The boom in tourism since 1990 is assumed to have caused severe deterioration of coral reefs, mangrove forests and seagrasses through direct degradation, and indirectly by sewage. ${ }^{8,9}$ Uncontrolled garbage disposal from an increasing population contributes significantly to the pollution of the coastal waters via surface water run-off and leaching. Onsite waste treatment facilities are often not in place and the local population including many hotels discharge untreated wastes into the sea. Moreover, drifting garbage such as plastic bags can accidentally be mistaken for jellyfish and eaten by turtles, resulting in increased turtle and seabird mortality. Fortunately, Zanzibar banned the use of plastic bags in 2012 reducing this problem. Unsystematic waste management has a negative impact not only on the coastal environment around the Island, but also on tourism industry, public health, socio-economy.

To support this growth in native population and visiting tourists, fisheries have exploded over recent years, with annual catches rising seven fold from around 5000 to 34000 tons over the last 3 decades (Table 1). This increase was mainly driven by off shore fisheries with an increasing number of larger boats. After a peak in total fish landings in the early 1980 's, catches have been low until a gradual and continuing increase from around 2000. There is a data gap in the estimated number of fish catches for several years (Table 1). Similarly, there is only rudimentary information on the assessment of fish stocks, making it very difficult to set regulation targets.

In addition, the total energy demand on Zanzibar has doubled since 1990 and is expected to increase by $50 \%$ over the next decade. While all of the electricity comes from mainland, mangroves provide approximately $70 \%$ of the total energy used on the Island, ${ }^{24}$ contributing severe pressure on mangrove habitats.

\section{Increasing sea surface temperatures and sea level}

Similar to many other coastal waters in the Western Indian Ocean, sea surface temperatures have risen with a rate of about $0.1^{\circ} \mathrm{C}$ per 
decade. (Figure 1) While significant year-to-year differences exist, reoccurring El Nino events stand out clearly. Looking more carefully at El Niño events in 1998 and 2016, these years are associated with periods of up to five weeks, with water temperatures above $29.8^{\circ} \mathrm{C}$. (Figure 2) This temperature is regarded as a detrimental threshold above which severe coral bleaching is known to occur ${ }^{25}$ and used in NOAA's worldwide Coral reef watch program to evaluate coral reef stress levels.

Table I Long-term changes in annual fish catches (tons) reported for Zanzibar. Jiddawi and Ngoile (1999) provided data from 1980 to 2000 and the Department of Fisheries in Tanzania provided recent data from 2008 to 2015. nd, not determined

\begin{tabular}{cc|cc}
\hline Year & Catches & Year & Catches \\
\hline 1980 & 4093 & 1998 & 14456 \\
1981 & 5492 & 1999 & 13212 \\
1982 & 23109 & 2000 & 13731 \\
1983 & 26114 & 2001 & nd \\
1984 & 23161 & 2002 & nd \\
1985 & 14145 & 2003 & nd \\
1986 & 11399 & 2004 & nd \\
1987 & 16269 & 2005 & nd \\
1988 & 11451 & 2006 & nd \\
1989 & 12435 & 2007 & nd \\
1990 & 9430 & 2008 & 24803 \\
1991 & 8342 & 2009 & 25396 \\
1992 & 12280 & 2010 & 25695 \\
1993 & 10259 & 2011 & 28759 \\
1994 & 10829 & 2012 & 29411 \\
1995 & 10518 & 2013 & 30712 \\
1996 & 11710 & 2014 & 32974 \\
1997 & 10725 & 2015 & 34104 \\
& & &
\end{tabular}

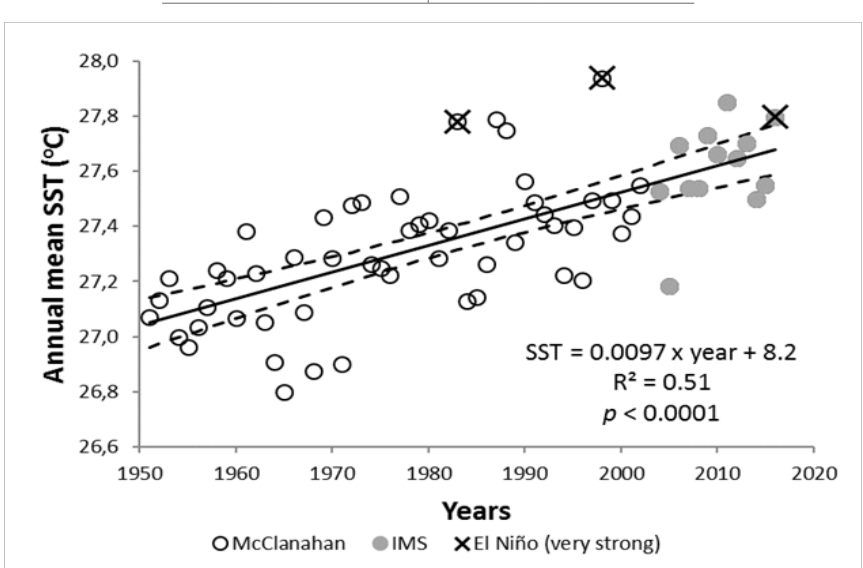

Figure I Development in sea surface temperatures (SST) derived from satellites. Open circles are data from McClanahan et al. (2007). Grey circles are data from the Institute of Marine Science on Zanzibar (Muhando unpublished). Black crosses represent very strong El Niño years. In addition, we show the regression line (solid line) and the upper and lower $95 \%$ confidence limits (dashed lines).
Based on analysis of sea level anomalies (Table 2), we found a gradual long-term rise in sea level of approximately $1 \mathrm{~cm}$ per decade since the measurements began in 1984 in agreement with. ${ }^{26}$ However, with a much faster rate (approximately $8 \mathrm{~cm}$ per decade) is observable since 2000 , suggesting that increases in water level are accelerating in recent years. In either case, local water levels appear to be rising rapidly raising concerns for improved coastal protection by mangroves and seagrass meadows, decreasing at a currently unknown rate. According to Ngusaru et al., ${ }^{9}$ a sea level rise of $1 \mathrm{~cm}$ will cause a shoreline recession of $1.0-1.5 \mathrm{~m}$ in this region.

Table $\mathbf{2}$ Changes in sea level in the waters of Zanzibar.Annual mean recordings of sea level were calculated based on daily measurements in Stone Town harbor. The table shows the development in the annual differences to the overall mean water level (sea level anomalies $(\mathrm{mm})$ ). Using a linear regression analysis, we found a weak increase in sea level with time (Sea level anomaly $(\mathrm{mm})=1.2 \times$ year $\left.-19.3 \mathrm{~mm}, \mathrm{r}^{2}=0.10, \mathrm{p}=0.08\right)$. The slope of the regression line of $1.2 \mathrm{~mm}$ per year represents an increase in water level by approximately I $\mathrm{cm}$ per decade.A similar regression analysis for the period 2000 to 2016 gives a slope of $8.6 \mathrm{~mm}$ per year $\left(r^{2}=0.83, p<0.00 I\right)$.

\begin{tabular}{cccc}
\hline Year & $\begin{array}{c}\text { Seal level } \\
\text { anomaly }\end{array}$ & Year & $\begin{array}{c}\text { Seal level } \\
\text { anomaly }\end{array}$ \\
\hline 1984 & 24 & 2000 & -59 \\
1985 & 7 & 2001 & -71 \\
1986 & -8 & 2002 & -43 \\
1987 & 10 & 2003 & -17 \\
1988 & 27 & 2004 & -9 \\
1989 & -34 & 2005 & -14 \\
1990 & 14 & 2006 & -7 \\
1991 & 27 & 2007 & 38 \\
1992 & -35 & 2008 & 19 \\
1993 & -18 & 2009 & 21 \\
1994 & -26 & 2010 & 55 \\
1995 & -4 & 2011 & 56 \\
1996 & -32 & 2012 & 21 \\
1997 & -45 & 2013 & 34 \\
1998 & 23 & 2014 & 63 \\
1999 & -20 & & \\
\hline
\end{tabular}

\section{Evidence of environmental impacts from baseline studies}

\section{Marine litter}

Marine litter and primarily plastic debris in the ocean is now ubiquitous worldwide. Plastics have been used increasingly in place of more traditional materials in many sectors, including construction, transportation, fishery, household goods and packaging, and subsequently there is both land-based and sea-based sources to the massive occurrence of litter in the marine environment including in the Western Indian Ocean. ${ }^{27}$

From a preliminary beach litter survey conducted along the western shoreline north of Stone Town (Beit el Ras) in February 
2016, litter items, corresponding to $369 \mathrm{~kg}$ of litter larger than $2.5 \mathrm{~cm}$, were collected over a $100 \mathrm{~m}$ stretch of the shoreline. Several car tyres $(180 \mathrm{~kg})$ were presumably left at the beach for leisure purposes by local inhabitants; hence these items were marked but not removed, and not used for further analysis of beached marine litter. Analysis of marine litter items collected, showed that the plastic litter was a major contributor per weight (46\%), followed by the category of material "cloth" (34\%) and "other" - mixed material category (10\%). The distribution of litter types within the category "plastic" demonstrated that items related to fishing activities (e.g., fishing gear -lures, traps and pots-, monofilament line, rope, fishing net, strapping) contributing to the major part of plastic litter $(67 \%)$, followed by the construction material, i.e. brick, cement, pipes (20\%), plastic bags and debris related to food products (5\%), and plastic shoes (4\%) (Figure 3A).

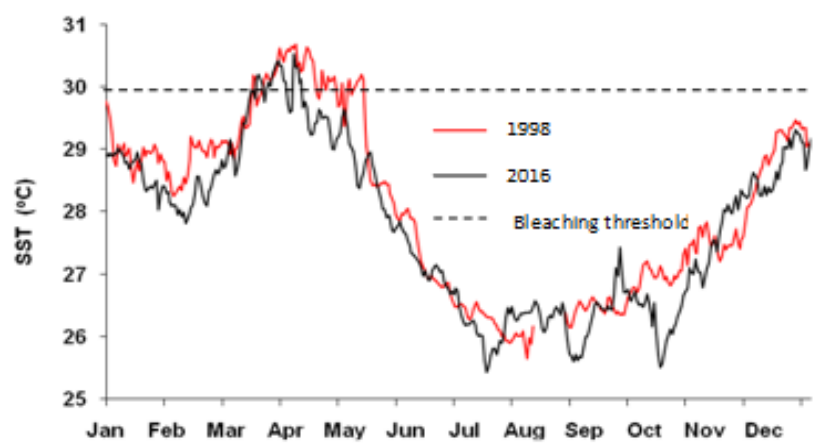

Figure 2 Comparison of the sea surface temperature during two mass coral bleaching years(1998 and 2016)in the Chumbe Reef Sanctuary. Temperature data were recorded using temperature loggers from the Institute of Marine ience on Zanzibar (Muhando unpublished). The dotted line represents the bleaching threshold temperature of $29.8^{\circ} \mathrm{C}$.

Analysis of microplastic particles in sediment samples from the upper part of the tidal zone at the beach, showed that most particles in the range $250 \mu \mathrm{m}-25 \mathrm{~mm}$, were between 1 to $5 \mathrm{~mm}$ in size with densities up to 30 particles per $\mathrm{kg}$ sediment (Figure 3B). Mean number $(\mathrm{n}=5)$ of microparticles at Beit el Ras station, in February 2016, was 36 particles per $\mathrm{kg}$ beach sand, with the particles of $1-5 \mathrm{~mm}$ being a major size-fraction, and flakes being a major shape-fraction, followed by the films and filaments.

It is difficult to make a direct comparison with other countries from tropical region, due to the variation of the measurement units However, an estimate for other areas from the tropical region as number of microplastic particle per $250 \mathrm{~mL}$ of sediment collected at sandy beaches: Mozambique, number of microplastic particles 2130; Philippines, 1-10; Oman, 11-20; Dubai, United Arab Emirates, 1-10; Australia, Port Douglas, 1-10. ${ }^{27}$ Microplastic, consisting at least seven groups of synthetic polymer materials, has been identified with FT-IR spectroscopy with polyethylene (PE), polypropylene (PP) and polyethylene terephthalate (PET) as the dominant types.

\section{Water quality}

Untreated municipal wastewater, discharged into coastal waters and in some places directly onto coastal habitats, has deleterious effects on the natural environment and potentially on the economic base that many of the islanders depend. Currently, there are 27 sewage outfalls around Unguja Island estimated to discharge around $2,200 \mathrm{~m}^{3}$ of untreated liquid waste into the Indian Ocean on a daily basis. ${ }^{29}$ Coastal pollution is potentially threatening the health of mangroves, seagrass beds and coral reefs thus putting at risk the livelihoods of several coastal communities. Pollution emanating from municipal sources has also been directly linked to frequent outbreaks of waterborne diseases such as cholera, diarrhea and gastroenteritis, especially during the rainy seasons. ${ }^{22,30}$ Sewage pollution is accordingly also threatening the burgeoning tourism trade that is playing an increasingly important role in the development of the Island. ${ }^{1,30}$

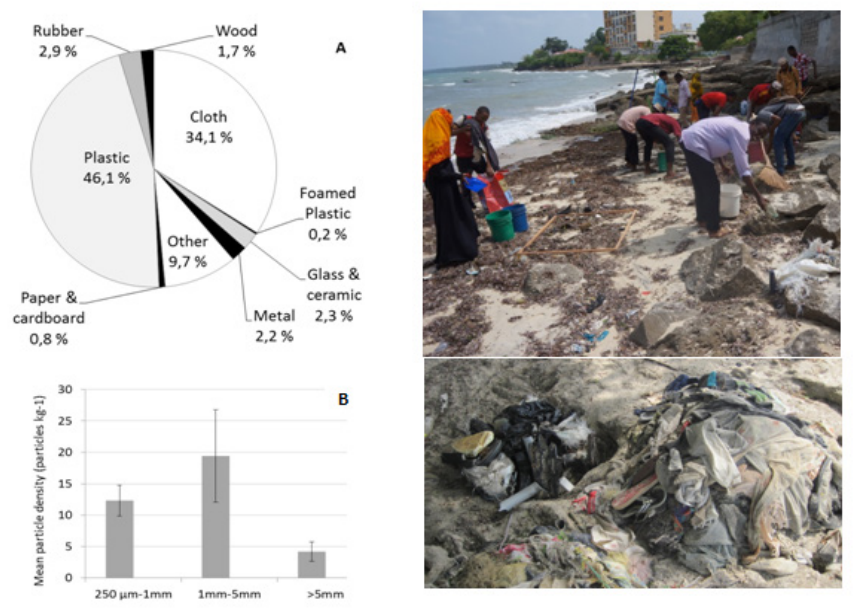

Figure 3 Marine litter survey along a $100 \mathrm{~m}$ stretch of a beach a few $\mathrm{km}$ north of Stone Town. The composition of large litter items (A) was characterized by weights $(\mathrm{kg})$ in percent. The concentrations of microplastic and mesoplastic (5-25 mm) particles identified from beach sediments (B) were counted under a stereo scope and shown as mean \pm standard error, $n=5$. Photos by $Z$. Tairova and J. Strand.

Historical records of the loading of nutrients and organic matter into the coastal zone is virtually absent. The data shown in Figure 4 therefore only represents a snapshot of the levels found around Unguja Island. As expected nutrients (inorganic phosphorus), phytoplankton biomass (Chla) and coliform fecal bacteria levels were elevated near the densely populated city of Stone Town on the west coast. More surprisingly was the elevated levels in the northern and eastern more remote areas, suggesting strong impact of the recently established huge hotel resorts along the coastline (Figure 4). Concerning phytoplankton biomass, satellite data during June 2015 (two weeks after sampling) on the spatial distribution of Chla similarly indicates elevated levels along the west coast of Unguja Island. ${ }^{1}$ These maps furthermore suggest that these nearshore blooms are connected with off shore blooms originates from mainland sources around Dar es Salam. While no long-term consistent records are available to compare these results with, a few studies from the late 1990ies do suggest that levels of nutrients, phytoplankton and coliform bacteria have increased (Figure 4). However, flushing and complex hydrodynamics driven by tides, wind conditions and regional currents ${ }^{1,31}$ likely have a strong influence on the observed local variations in water quality. Future studies therefore needs to take account of the complex hydrodynamics to adequately determine the sources and levels of contaminants around the Islands.

As part of our previous baseline studies we investigated evidence of hazardous chemical substances such as TBT associated with antifouling paints, and PAH's metabolites related to pollution of 
oil residues. Not surprisingly, we found high levels of both TBT and PAH metabolites using a combination of bio-indicators such as bivalves, gastropods and demersal fishes and passive samples. Levels of both TBT and PAH-metabolites are generally elevated in coastal waters nearby Stone Town, but we have very little historical data for comparison purpose.
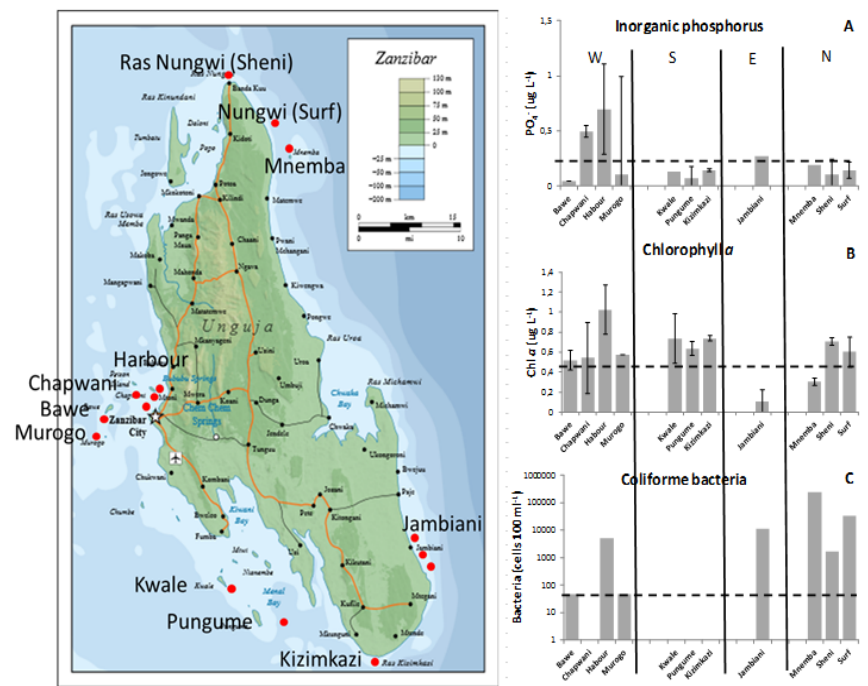

Figure 4 Levels of A) inorganic phosphorus, B) phytoplankton biomass (Chla) and C) coliform fecal bacteria sampled in the coastal waters around Unguja Island (unpublished data from DANIDA BSUII baseline study). Values are means $\pm S D$. The horizontal dashed line in A) represents concentrations of inorganic phosphorus reported in coastal waters near Stone town in 1996 to 1997. ${ }^{49}$ The dashed line in B) represents the average Chla level reported by Lugomela et al. (200I) near Bawe Island during May to June 1999. The dashed line in C) represents a recommended bathing water threshold for coliform bacteria in marine coastal waters (EU Bathing Water Directive 2006/7/EC).

The levels of TBT in tissue of gastropods and bivalves ranged from $<1$ to $25 \mu \mathrm{g} \mathrm{TBT} \mathrm{kg}^{-1}$ wet weight with highest concentrations found near the port of Stone Town. In addition, occurrence of imposex, which is regarded as TBT-specific bioindicator, were found in two for native neogastropod species (Morula granulata and Nassarius corotatus) around Stone Town indicating that the environmental impact of TBT in Zanzibar coastal waters can still be found. In addition, TBT levels in some of the mollusc samples exceeded the recommended food quality criteria threshold $\left(15.2 \mu \mathrm{g} \mathrm{kg}^{-1}\right.$ w.w.) for edible fishery based on the WHO recommended maximum daily intake of $0.25 \mu \mathrm{g} \mathrm{kg}^{-1}$ body weight per day ${ }^{32}$ and an average fish consumption of an EU citizen is $115 \mathrm{gd}^{-1} \cdot{ }^{33}$ In comparison, the estimated daily intake of fishery products per year is estimated to be $25-40 \mathrm{~kg}$ per year (corresponding to $70-100 \mathrm{~g}$ per day) by Zanzibaris. ${ }^{34}$

Concentrations of TBT in coastal sediments around Zanzibar have previously been reported to be in average $4340 \mu \mathrm{g}$ TBT $\mathrm{kg}^{-1}$ dry weight, again with highest levels detected near the port in Stone Town. ${ }^{36}$ Overall, levels of TBT detected in Zanzibar's coastal areas pose a serious health threat and demographic landscape to marine organisms mainly gastropods and bivalves. The main possible contamination sources are from shipping activities; however, it is presently unknown whether it can be related to remains from previous or current TBT usages in Zanzibar waters. An international ban on the use of TBT as antifouling agent was entering into force in 2008, but several east African countries including the United Republic of Tanzania have not yet ratified this treaty. ${ }^{36}$
Low molecular weight PAHs of two to three benzene rings are more acutely toxic to aquatic organisms, resulting in growth and survival impairments or reproduction abnormalities, while high molecular weight PAHs of four or more than four benzene rings are carcinogenic and mutagenic and exhibit endocrine disrupting activity in higher level organisms with less acute toxicity. ${ }^{37}$ In a previous study by Kamaria (2015), 11 out of 16 priority PAHs were detected in sediments along the coasts of Unguja and Pemba Islands with PAH levels ranging between 1.53 to $11.90 \mathrm{ngg}^{-1} \mathrm{~d}$.w. In comparison, PAHs levels reported in fish tissues, during our 2016 baseline survey, ranged from 0.028 to $0.037 \mathrm{ngg}^{-1} \mathrm{~W}$.w. with highest concentrations near the Stone Town harbor. ${ }^{38}$

In a baseline study, we investigated the use of a local goby fish (Periophthalmus sobrinus) as a bio-indicator for PAH metabolites around Zanzibar. The PAH levels in biliary bile ranged between 99-690 ngml $^{-1}$ (expressed as 1-hydroxypyrene equivalents) and showed the highest levels nearby Stone Town compared to the more remote small islands, indicating the harbor as the origin of PAH sources in these waters. The measured levels were several fold higher than background assessment criteria (BAC) for 1-hydroxypyrene, recommended by ICES and OSPAR for this biomarker in other demersal fish species, i.e. in the bile of dab (Limanda limanda), cod (Gadus morhua), flounder (Platichthys $s p$.) and haddock (Melanogrammus aeglefinus). ${ }^{39}$ Also, using similar fluorescence method, we found in three out of four sampling stations, that PAH metabolite levels in fish from Zanzibar was higher than BACs in dab $\left(150 \mathrm{ng} \mathrm{m}^{-1}\right)$, but lower than in cod, flounder and haddock, where BACs range within 1100-1900 $\mathrm{ng} \mathrm{ml}^{-1} .40$ The levels of PAH metabolites measured in goby fish from Zanzibar were nevertheless lower than environmental assessment criteria (EAC) used for similar demersal bio indicator species by ICES and OSPAR.$^{39}$ Detection of billiary PAH metabolites highlights a potential of the species as bio indicator for PAH pollution monitoring in tropical waters.

\section{Benthic habitat health}

\section{Evidence from long term monitoring of coral reefs}

Thriving coral reefs around Zanzibar are important for coastal fishery, coastal protection, tourism industry and biodiversity conservation. ${ }^{1,5,40,41}$ Both, fringing and nearshore patchy reefs have been deterioring globally ${ }^{42-44}$ and locally ${ }^{43}$ deterioring through anthropogenic climate change threats such as more frequent and intensified El Niño years and related mass coral bleaching events. Physical disturbance by destructive resource practices such as fishing operations and diving, coastal construction and mass occurrence of the echinoids crown-of-thorns starfish (COTS), further exacerbate the negative impact of global warming on coral health around Zanzibar. ${ }^{10,45,46}$ Furthermore, hazardous chemical pollution from untreated sewage waters, shipping, and nutrients contribute to the deterioration of coral reef health and allied ecosystems ${ }^{47}$ Coral reef degradation is therefore, expected to continue with increasing costal population, climate warming and pollution. ${ }^{20}$

On most of the monitored reef sites around Unguja and Pemba Islands, a severe decrease in the presence of temperature sensitive Acropora species has been observed since the mid 1990's. ${ }^{10}$ The fringing reef at Changuu, ca. $3 \mathrm{~km}$ west of Stone Town, gives an example of this development (Figure 5). Although the reef has only experienced a small decrease in overall live hard coral cover, a significant increase in dead corals and overgrowth of algae has 
occurred over the last decade. ${ }^{10}$ It is noteworthy that these trends were more evident after strong El Nino years (1998 and 2016).
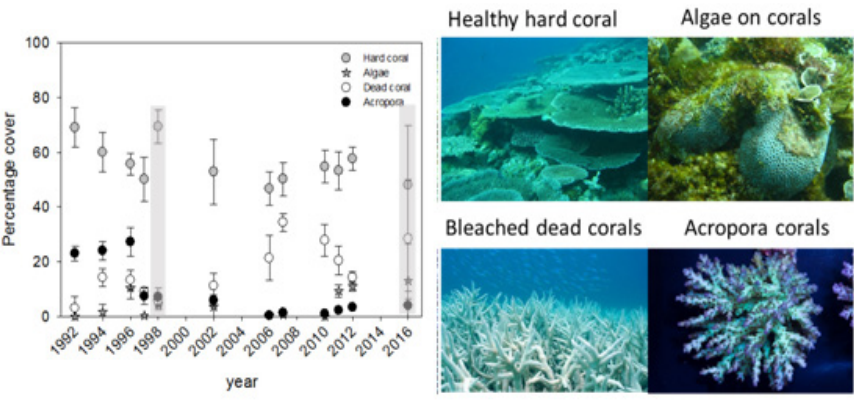

Figure 5 Long-term developments in coral reef health of Changuu Island. Changes are shown for cover of live hard corals, macroalgae, dead corals and Acropora species from 1992 to 2016. Grey shaded areas indicate El Niño years. Photos to the right show coral of different health status (Unpublished data from A. Ussi and C.A. Muhando). Photos by A. Ussi.

Several reef sites around Zanzibar have furthermore been invaded by high numbers of COTS since 2004. ${ }^{10,45}$ This species has a preference for Acropora species and might have influenced the recovery from the 1998 El Niño event. ${ }^{10}$

\section{Coral reef bleaching studies}

High sea surface temperatures (SST) experienced in 1998 were global and unprecedented causing 25 to $50 \%$ of the corals in the Zanzibar area to bleach (loss of symbiotic algae). ${ }^{48}$ Bleaching also occurred inside the Chumbe Reef Sanctuary(CRS) and led to the first mass coral-bleaching event with $30 \%$ hard coral mortality, predominantly occurring on Acropora species. ${ }^{49}$ Under severe bleaching, dead corals become colonized by macroalgae or soft corals, also causing a decline in dive tourism. ${ }^{49}$ However, the CRS managed to survive the 1998 bleaching event relatively unscathed due to few other stressors being present (i.e. no fishing or destructive activities take place). Other reefs (Changuu and Chapwani near Stone Town; (Figure 4) were reported to have less than $40 \%$ survival after bleaching. ${ }^{48}$

By 2016, Zanzibar was again severely impacted by high SST from the end of March until beginning of April, leading to the second, severe coral-bleaching event in the CRS with about $80 \%$ bleaching across the entire reef sanctuary (Figure 6). As part of its bleaching management planning in 2014, Chumbe Island Coral Park (CHICOP) established a simplified web-form in cooperation with the Coastal Oceans Research and Development Indian Ocean (CORDIO) project, and submitted bleaching observations and data from the CRS throughout 2016. As shown in Figure 6, live hard coral cover in the CRS decreased by 32$34 \%$ overall with almost $50 \%$ hard coral mortality in the shallow reef parts by September 2016.

\section{Evidence from monitoring of seagrasses and mangroves}

Seagrasses of the genus Thalassodendron, Thalassia, Cymodocea $\&$ Halodule are abundant around the Islands. ${ }^{50}$ Dense seagrass meadows occur mostly in shallow protected areas, in particular in lagoons and intertidal pools with soft substrate (Figure 7). ${ }^{1}$ As species composition, coverage and distribution of seagrasses have not been routinely monitored around Zanzibar, we have limited understanding of how seagrass health has evolved over time. Interviews with invertebrate gleaners around Zanzibar, however, suggest a general decline in distribution, both in seagrasses and in the density of invertebrate species associated with seagrasses during the last decade around Unguja Island. ${ }^{51}$ In comparison, a more local but detailed analysis of the submerged aquatic vegetation (SAV) cover, including seagrasses and macroalgae, was performed in Chwaka Bay over the study period 1986 to $2003 .{ }^{50}$ Overall, the satellite analysis showed no general increase or decrease of vegetation as there were areas with both loss and gains of SAV. From personal observations, many seagrass meadows are doing poorly with scattered, fragmented meadows often displaying heavy epiphyte overgrowth. While the cause of a likely overall decline in seagrasses around Zanzibar is uncertain, the fact that this degradation has occurred during the explosion in population density and tourism does suggest a linkage to enhanced levels of nutrient and dissolved organic matter from untreated sewage water. Such conditions can have a huge negative impact on seagrasses by reducing water clarity and stimulating overgrowth of epiphytes, which in combination with extreme temperature events poses a severe stress on seagrasses. ${ }^{52}$ In addition, studies on the eastern side of Unguja Island indicate that cultivation of seaweeds can deteriorate local seagrass meadows. ${ }^{53}$
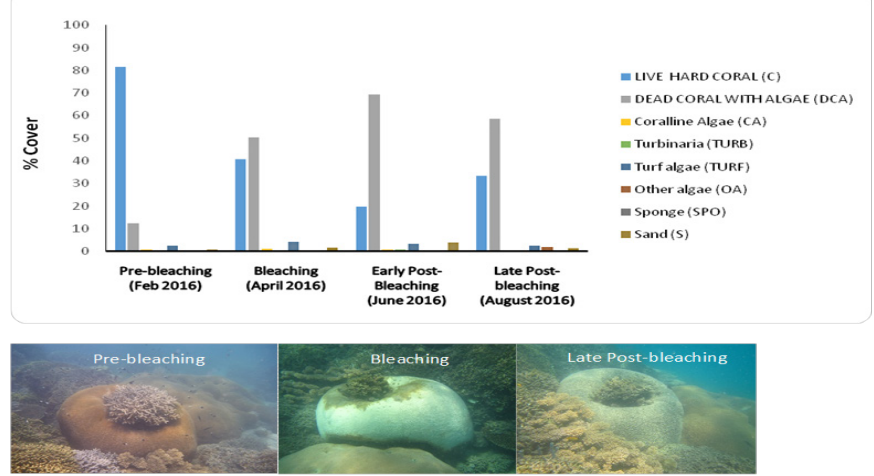

Figure 6 Coral reef monitoring data from the Chumbe Reef Sanctuary, located on the western side of Chumbe Island, about $10 \mathrm{~km}$ southwest of Stone Town. Top panel shows change in benthic coverage throughout the 2016 coral bleaching event. Bottom panel shows photos of hard corals inside the CRS which have been affected by temperature induced bleaching in 2016 (CHICOP (2017). Photos by U. Kloiber.

A recent report ${ }^{54}$ on the impacts of climate change on mangroves in Zanzibar waters, evaluated the status and development of mangroves based on existing datasets of both ecological and socio-economic surveys and supplemented these with field-based validation. Their results indicate that mangroves of Zanzibar are under increasing degradation from both anthropogenic pressures and climate change and variability. Current use of mangroves is considered unsustainable, and there is an eminent need for restoration of degraded mangrove stands involving local communities and science-based management. The first mangrove management plan for Zanzibar was drawn in $1950^{55}$ following a reconnaissance survey on the forest problems of then Zanzibar Protectorate. Mangrove degradation in Zanzibar has however continued unabated since then. The results presented by Mangora et al..${ }^{54}$ show that despite that mangroves are currently protected by law, many have been destroyed or are under threat of destruction as they are continually exposed to the increasing demand of the wood resources from the growing population. 


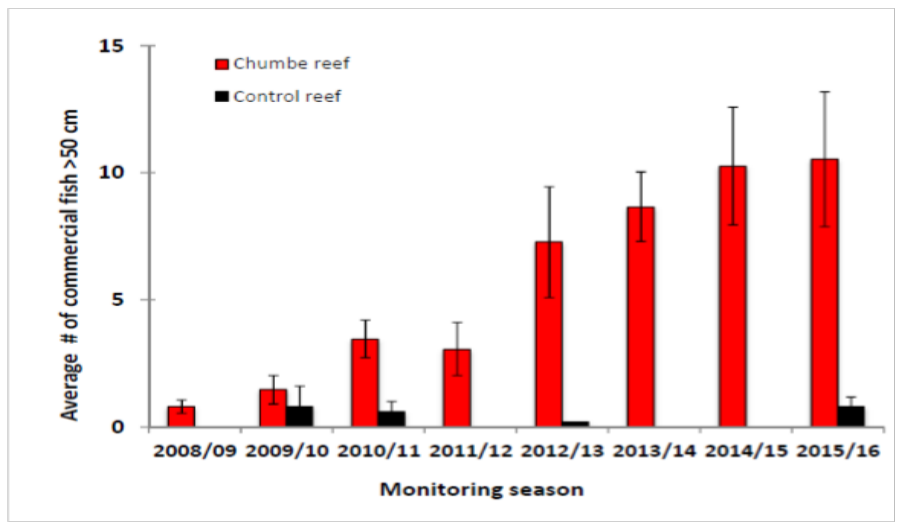

Figure 7 Effects of a strict No-Take-Area on the average number of large commercial fish (per $500 \mathrm{~m}^{2}$ ) inside the Chumbe Reef Sanctuary (CHICOP 2017). Error bars are $\pm I S D$.

\section{Management of threats and pressures}

\section{Protection against overexploitation of fish}

Effects of fisheries management was investigated in the Chumbe Reef Sanctuary from 2008 to 2016, by enforcing a strict No-TakeArea. This initiative significantly increased the average number of large commercial fish, such as reef snappers, inside the sanctuary compared to an unprotected control reef close-by (Figure 7). The protection of commercially important fish species allows them to grow and makes them exponentially more fecund than their smaller, younger counterparts.

\section{Removal of invasive species}

Crown of thorn starfish (COTS; Acanthaster planci) density reaching up to 3125 individuals per hectare was observed at Murogo reef in $2006 .{ }^{45}$ While the prior 1990's COTS outbreaks were shortlived, outbreaks in 2004 and 2006 were larger, lasted for more than a year and were much more destructive. At Murogo Island, the COTS population had a destruction rate of about $200 \mathrm{~cm}^{-2} \mathrm{~d}^{-1} \cdot{ }^{10}$ Reef stakeholders in Zanzibar have been periodically operating removal programs to rescue reef communities. Consistent removal of COTS by physical means was initiated in 2004 by CHICOP of which by December 2008 more than 3000 COTS were successfully removed from inside the Chumbe Reef Sanctuary (Table 3). Researchers at IMS have furthermore removed more than 3500 COTS from reefs off Zanzibar town (Bawe, Murogo, Pange and Nyange) in $2006 .{ }^{45}$ Department of Fisheries operates COTS control through both poisoning by syringe with copper sulfate and by physical removal when needed. Despite these management efforts, COTS infestation remains to be among the important threats to thriving of reef communities in Zanzibar. While the number of COTS have decreased dramatically, their size distribution remains unchanged, with average sizes ranging between 23 to $38 \mathrm{~cm}$. This investigation shows that in a relatively small reef area, manual removal of COTS is a viable option for maintaining or improving reef health and for improving coral recovery prospects after large natural disturbances. ${ }^{21,45}$ Currently, CHICOP is investigating environmentally sustainable density thresholds for COTS. This will enable proper management and trigger the removal of COTS when necessary, as COTS are a part of the ecosystem, and removal at low densities may not be necessary.
Table 3 Results of successful removal of Crown of Thorns Starfish (COTS) from the Chumbe Reef Sanctuary since 2004. COTS are considered destructive to coral reef health when they reach a density of 15 individuals per hectare. Since 2009, the density of COTS has stabilized and only few individuals were removed over the last five years (CHICOP 20I7). An example of the impact of COTS outside the Chumbe Reef Sanctuary is shown to the right. Photo by U. Kloiber.

\begin{tabular}{cc}
\hline Year & $\begin{array}{c}\text { \#COTS } \\
\text { removed }\end{array}$ \\
\hline 2004 & 1225 \\
2005 & 1597 \\
2006 & 342 \\
2007 & 247 \\
2008 & 227 \\
2009 & 27 \\
2010 & 67 \\
2011 & 43 \\
2012 & 51 \\
2013 & 99 \\
2014 & 57 \\
2015 & 34 \\
\hline
\end{tabular}

\section{Stakeholder engagement}

The two-day workshop involving local and Danish marine scientists, as well as stakeholders engaged in regional management of coastal resources, made it clear that more knowledge is needed on the pressures and status of the marine environment (Table 4). Since this meeting, a concept note on the need for longer-term marine coastal monitoring, was written and presented to the local government. In addition, the establishment of a marine coastal monitoring program with emphasis on coral reef health has become a corner stone in a continuation of a DANIDA funded project on Zanzibar. The monitoring program is considered essential to set clear environmental targets and for future evaluation of the expected effects of enforced regulations. In parallel to the establishment of a long-term marine environmental monitoring program, an important factor will be local capacity building initiatives at various levels. This includes improved education of students and improved field and laboratory facilities at the State University of Zanzibar. Gained understanding of seasonal patterns and coupling of ecosystem health to human pressures, will be used to optimize environmental targets and be disseminated to local and regional stakeholders. In addition, understanding of these matters will be disseminated to the local population on Zanzibar to raise awareness of the development and status of the marine environment. Especially local coastal communities, who are the foremost stakeholders, should be involved in the planning, decision and implementation of projects aiming to restore and regulate coastal resources, to reduce conflicts and ensure long-term sustainable use of the marine environment. ${ }^{4}$ 
Table 4 Identified marine environmental, related causes ( pressures), knowledge gaps and needed action. The information presented derives from a two-day workshop with environmental scientists and stakeholders on Zanzibar. MPA is Marine Protected Areas, NTA is No Take Areas.

\begin{tabular}{|c|c|c|c|}
\hline Environmental problem & Cause of problem & Knowledge gaps & Action needed \\
\hline Polluted beaches & $\begin{array}{l}\text { - Inproper waste treatment } \\
\text { Unregulated waste disposa- } \\
\text { land treatment }\end{array}$ & $\begin{array}{l}\text { - Amount, type and origin } \\
\text { of waste } \\
\text { - } \quad \text { Environmental impact }\end{array}$ & $\begin{array}{l}\text { - Upgrading the solid waste dis- } \\
\text { posal and treatment systems } \\
\text { Enforcement of environmental } \\
\text { regulations } \\
\text { Enforcement of public awareness } \\
\text { programs and supporting of civil } \\
\text { society actions, as beach cleaning } \\
\text { activities }\end{array}$ \\
\hline $\begin{array}{l}\text { Reduced water quality, } \\
\text { reduced health of corals and } \\
\text { seagrasses } \\
\text { Contamination of fish and } \\
\text { invertebrates by hazardous } \\
\text { substances }\end{array}$ & $\begin{array}{l}\text { - } \\
\text { - } \\
\text { Poorly regulated tourism and } \\
\text { industries } \\
\text { - } \quad \text { Climate change } \\
\text { - } \quad \text { Unvasive species } \\
\text { Use of antifouling paints }\end{array}$ & $\begin{array}{l}\text { Loading of organic and } \\
\text { inorganic pollutants from } \\
\text { land and shipping to sea } \\
\text { Importance of sustainable } \\
\text { tourism } \\
\text { Regional and seasonal } \\
\text { distribution of pollutants } \\
\text { and invasive species } \\
\text { Longer-term changes in } \\
\text { health state of corals and } \\
\text { seagrass meadows }\end{array}$ & $\begin{array}{l}\text { - Upgrading the sewage network, } \\
\text { treatment plants including hotels } \\
\text { Monitoring of changes in human } \\
\text { pressures and environmental } \\
\text { state and impacts } \\
\text { - Establishment of a Long-Term } \\
\text { marine Monitoring program of } \\
\text { Zanzibar waters (LTMZ) } \\
\text { Establishment of MPA }\end{array}$ \\
\hline $\begin{array}{l}\text { Declining fish stock and } \\
\text { imbalanced food webs }\end{array}$ & $\begin{array}{l}\text { - Overfishing } \\
\text { - Destruction of habitats }\end{array}$ & $\begin{array}{l}\text { - Sustainable fishing levels } \\
\text { Importance of coastal } \\
\text { ecosystems to the liveli- } \\
\text { hood, tourism }\end{array}$ & $\begin{array}{l}\text { - } \quad \text { Fish stock assessment } \\
\text { Awareness raising on ecological } \\
\text { and economical value of coastal } \\
\text { ecosystems } \\
\text { - Enforcement of fishing regula- } \\
\text { tions } \\
\text { Establishment of NTA's }\end{array}$ \\
\hline Mangrove degradation & $\begin{array}{l}\text { Poorly regulated use of man- } \\
\text { groves for fire and building } \\
\text { materials }\end{array}$ & $\begin{array}{l}\text { - } \quad \text { Rate of mangrove remov- } \\
\text { al and degradation } \\
\text { - Possible recovery } \\
\text { Importance of sea level } \\
\text { rise }\end{array}$ & $\begin{array}{l}\text { - Monitoring of mangrove extent, } \\
\text { health and rate of degradation } \\
\text { Investment in mangrove replan- } \\
\text { tation }\end{array}$ \\
\hline
\end{tabular}

\section{Conclusion and recommendations}

There are several forces affecting the ecosystem health of Zanzibar coastal waters. Many of these appear to be strongly and increasingly influenced by human activities such as fishing, tourism, and disposal of waste reducing the quality and abundance of key coastal marine habitats dominated by seagrasses, mangroves and coral reefs. This conclusion supports a recent analysis which found that the main driver behind degradation of the coastal zone is the uncontrolled and poorly managed increase in population, urbanization and shoredwelling tourism. ${ }^{1}$ Evidence of this pressure is clear from high levels of marine litter, nutrients, phytoplankton and fecal bacteria, especially near urban areas. In addition to these, measurements of hazardous substances such as TBT and PAH indicate high levels associated with shipping activities, threatening not only the health of coastal ecosystems, but also human health. While evidence of these human related pressures are becoming stronger, knowledge about these have been around for several decades, ${ }^{55,9}$ and the need for better management of marine pollution has been identified some time ago. ${ }^{22}$ Nevertheless, the actual extent of these pressures and their influence of key marine habitats of Zanzibar waters remain widely uncertain. This is not surprising given the complexity of the conditions at play. For Zanzibar waters, corals give a good example of these complexities (Figure 8). The health of a given coral reef is the result of multiple biotic and abiotic factors interacting at different time and spatial scales. ${ }^{56}$ The main anthropogenic threats to the coral reefs of Zanzibar include overexploitation, destructive activities (fishing and anchor damage), and pollution..$^{57}$

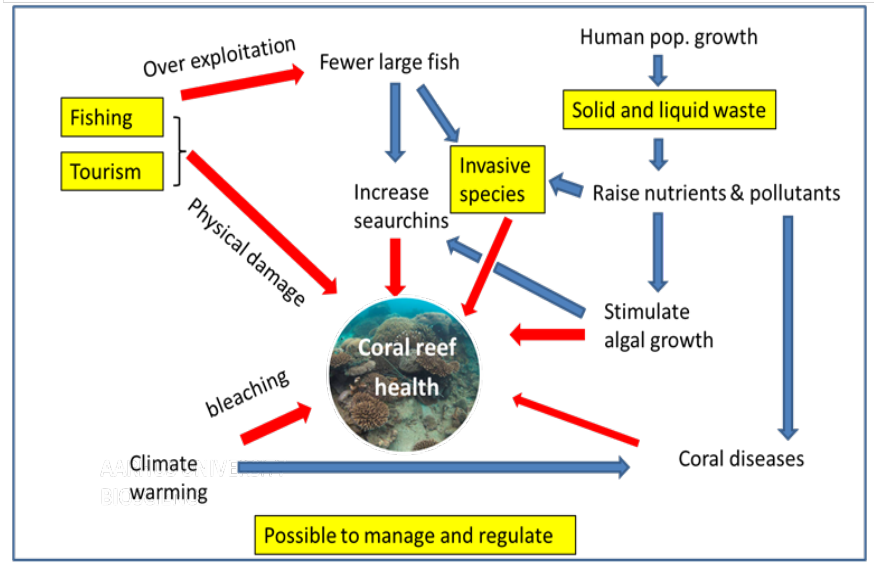

Figure 8 Relations between pressures and marine coastal ecosystem health with indication (yellow boxes) of problems, which can be managed and regulated. 
Various types and combinations of human and natural perturbations may cause significant changes, eg. Coral reef health, evoked by even small changes in a key parameter. ${ }^{58}$ As an example of the complexity of these interactions, a COTS out break on coral reefs, is in itself believed to be sensitive to the increased human activities causing ocean pollution, but can also be contributed to excessive fishing removing its key predators..$^{10}$ Unfortunately, there are no studies relating the apparent trend in COTS to water pollution or fisheries in the area. It is also not clear whether the outbreak of COTS in the area is native or is a result of immigration, and there are several hypotheses on the causes of COTS outbreaks. With the combination of coastal construction activities, ocean directed sewage disposals seems likely to have deteriorated water quality in coastal waters. In addition, high growth rate of coastal human populations and growing tourism industry have triggered extensive and intensive harvesting of edible marine resources in order to meet their nutritional demand. This in turn has led into overfishing of both finfish (such as puffer fish (Tetraodontidae), triggerfish (Balistidae), and maoriwrasses (Cheilinus sp.) and shellfish such as giant triton (Charonia sp.) which are natural predators of COTS.

In order to reduce such knowledge gaps, more systematic gathering of data is required. We advocate for the establishment of a Long-Term marine coastal Monitoring program for Zanzibar (LTMZ) as a first important step where standardization ensuring quality and comparability is of essence. ${ }^{9}$ This will not only provide a better understanding of the environmental health status, but also help elucidate the interacting forces of multiple human and natural pressures. Such an LTMZ monitoring program will also help set environmental targets, and be essential for local authorities to evaluate the success of necessary regulation. It should be emphasized that monitoring is an essential part of effective marine management, as improved knowledge facilitates the planning of more cost-effective recovery measures. ${ }^{59}$ While our local knowledge about pressures and responses of the Zanzibar marine environment is limited and fragmented, this should not impede development and implementation of local action plans. Although the Zanzibar government has taken initiatives such as the Zanzibar Land use plan to protect the health of the coastal ecosystems, this has so far not been sufficient to restore the situation. Monitoring data from a privately managed marine protected area presented here, fortunately suggest that environmental recovery is indeed possible and emphasizes the need for establishment of sustainably managed and protected coastal and marine areas around Zanzibar. These should be established in agreement with national and international laws and based on the best available scientific information as outlined in the UN Sustainable Development goal (SDGD target 14.5). Existing networks among research groups, fishing communities and tourism industries operating on the Island, does encourage achievement of a long-term sustainable use of the rich marine environment of Zanzibar. Nevertheless, interests may differ among stakeholders. To facilitate optimal collaboration, we support previous suggestions for a participatory management approach, which invokes responsibility among all locally active players. ${ }^{22,60-61}$

\section{Acknowledgements}

This paper is a result of a marine baseline studies, conducted under the framework of the DANIDA capacity building project under the Building Stronger Universities phase II, supported by the Danish Ministry of Foreign Affairs. Authors would like to acknowledge the
State University of Zanzibar (SUZA-BSUII 14/16) for providing technical support in conducting this study. The appreciation is due to BSU II Project for funding the analysis and fieldwork. In addition, collaboration with marine researchers from local Universities, Government Agencies and NGOs based in Zanzibar, have provided important historical data enabling a contemporary understanding of the challenges facing the coastal ecosystems around Zanzibar and some of the possible solutions to these problems.

\section{Conflict of interest}

The author declare no conflict of interest.

\section{References}

1. Khamis ZA, Kalliola R, Käyhkö N. Geographical characterization of the Zanzibar coastal zone and its management perspectives. Ocean \& Coastal Management. 2017;149(15):116-134.

2. Wagner GM. Impacts of fishing (including dynamite fishing) on coral reef. Coral Reefs: Values, threats, and solutions, Proceedings of the National Conference on Coral Reefs, Zanzibar, Tanzania, Zanzibar, Tanzania.1997;38-44.

3. Feidi IH. The Fisheries of Zanzibar: Potential for New Investments. NAGA. World Fish Center Quarterly. 2005;28:37-40.

4. Masalu DCP. Coastal and marine resource use conflicts and sustainable development in Tanzania. Ocean \& Coastal Management. 2000;43(6):475-494

5. Lange GM, Jiddawi N. Economic value of marine ecosystem services in Zanzibar: Implications for marine conservation and sustainable development. Ocean \& Coastal Management. 2009;52:521-532.

6. OCGS. Office of the Chief Government Statistician, Zanzibar. Household budget survey 2014/15.Income and none income poverty preliminary results. Report. 2016.13 p.

7. http://data.un.org/

8. Bryceson I. A review of some problems of tropical marine conservation with particular reference to the Tanzanian coast. Biological Conservation. 1981;20(3):163-171.

9. Ngusaru AS. The present state of knowledge of marine science in Tanzania. Synthesis report. Tanzania coastal management partnership. Working Document: 5047 TCMP. 2000. 183 p.

10. Ussi AM. Population distribution and impact of crown-of thorns starfish, Acanthaster planci (L), on coral reefs of Zanzibar. Master Thesis, University of Dares Salaam, Tanzania. 2008.

11. Schreeb K. Mapping coastal biotopes and resource use in Zanzibar, Tanzania. Master Thesis. Department of Physical Geography, Stockholm University, Sweden. 2015.

12. Mc Clanahan TR. Seasonality in East Africa's coastal waters. Marine Ecology Progress Series. 1988;44:191-199.

13. Ngurasu A. Climate and oceanography. In: Richmond, Matthew D. editors. A Guide to the Seashore of Eastern Africa and the Western Indian Ocean Islands. SIDA, Sweden, SAREC. 1997. p. 8-11.

14. Mahongo SB, Shaghude YW. Modelling the dynamics of the Tanzanian coastal waters. Journal of Oceanography and Marine Science. 2014;5:1-7.

15. Cheshire AC, Adler E, Barbière J, et al. UNEP/IOC Guidelines on Survey and Monitoring of Marine Litter. UNEP Regional Seas Reports and Studies. 2009. 120 p. 
16. Grasshoff K, Kremling K, Ehrhardt M. Methods of seawater analysis. Wiley-VCH. $3^{\text {rd }}$ ed. Weinheim, Germany: Verlag GmbH; 1999. 600 p.

17. Strand J, Jorgensen A, Tairova Z. TBT pollution and effects in molluscs at US Virgin Islands, Caribbean Sea. Environment International. 2009;35(4):707-711.

18. Tairova ZM, Strand J, Chevalier J, et al. PAH biomarkers in common eelpout (Zoarces viviparus) from Danish waters 2012. Mar Environ Res. 2012;75:45-53

19. English S, Wilkinson C, Baker V. Survey manual for tropical marine resources. ASEAN Australian Marine Science Project: Living Coastal Resources, Townsville. 1994. 368 p.

20. Muhando CA. Coral reef monitoring in Tanzania: an analysis of the last 20 years. Western Indian Ocean Journal of Marine Science. 2009;8(2):203-214.

21. CHICOP. $3^{\text {rd }}$ Ten-year management plan for Chumbe Island Coral Park. 2017-2027.

22. Mohammed SM, Pollution management in Zanzibar:the need for a new approach. Ocean \& Coastal Management. 2002;45(4-5):301-311.

23. Mensah A. People and their waste in an emergency context: the case of Monrovia, Liberia. Habitat International. 2006;30(4):754-768.

24. Zanzibar Planning Commission. Zanzibar energy sector review. Technical paper. 2015 .

25. Liu G, Strong AE, Skirving WJ, et al. Overview of NOAA Coral Reef Watch Program's Near-Real-Time Satellite Global Coral Bleaching Monitoring Activities. Proceedings of the $10^{\text {th }}$ International Coral Reef Symposium, Okinawa. 2006;1783-1793.

26. Watkiss P, Pye S, Hendriksen G, et al. The economics of climate change in Zanzibar. Final Summary Report. 2012. 39 p.

27. UNEP. Marine plastic debris and microplastics-Global lessons and research to inspire action and guide policy change. United Nations Environment Programme, Nairobi. 2016

28. Browne MA, Crump P, Niven SJ, et al. Accumulation of microplastic on shorelines woldwide: Sources and sinks. Environmental Science and Technology. 2011;45(21):9175-9179.

29. Moynihan MA, Baker DM, Mmochi AJ. Isotopic and microbial indicators of sewage pollution from Stone Town, Zanzibar, Tanzania. Marine pollution bulletin. 2012;64(7):1348-91355.

30. Mohammed SM. A Review of Water Quality and Pollution Studies in Tanzania. Ambio. 2002;31(7-8):617-20.

31. Zavala-Garay J, Theiss J, Moulton M, et al. On the dynamics of the Zanzibar Channel. Journal of Geophysical Research Oceans. 2015;120(9):6091-6113.

32. WHO. WHO Guidelines for Drinking Water Quality, $2^{\text {nd }}$ ed. World Health Organization Recommendations. 1993. 75 p.

33. EU. Substance data sheet: Tributyltin and its compounds, Priority substance No. 30, CAS-No.;688-73-3(36643-28-4). Environmental Quality Standards (EQS), prepared by the Frauen hofer Institute, Germany. Common implementation strategy for the Water Framework Directive, Brussels. 2005. 37 p.

34. Jiddawi NS, Pandu VM. Summary of fisheries and resources information for Zanzibar. In: Sanders MJ, Sparre P, editors. Proceedings of the Workshop on the Assessment of the Fishery Resources in the Southwest Indian Ocean, Albion Mauritius. 1987;14-925.
35. Sheikh MA, Noah NM, Tsuha K, et al. Occurrence of tributyltin compounds and characteristics of heavy metals. International Journal of Environmental Science \& Technology. 2007;4(1):49-59.

36. http://www.imo.org/en/About/Conventions/StatusOfConventions/ Pages/Default.aspx.

37. Kanaki M, Nikolaou A, Makri CA, et al. The occurrence of priority PAHs, nonylphenol and octylphenol in inland and coastal waters of central Greece and the island of Lesvos. Desalination. 2007;210(13):16-923.

38. Rashid RJ, Salum N, Tairova Z, et al. Potential of Periophthalmus sobrinus and Siganus sutor as bioindicator fish species for PAH pollution in tropical waters. Regional Studies in Marine Science. 2017.

39. Davies IM, Vethaak D. Integrated marine environmental monitoring of chemicals and their effects. ICES cooperative research report. 2012.315

40. Muhando CA, Jiddawi NS. Fisheries resources of Zanzibar: Problems and recommendations: Large marine ecosystems of the Indian Ocean: Assessment, sustainability, and management. Malden, USA: Blackwell Science; 1998. p. 247-9254.

41. Jiddawi NS, Öhman MC. Marine fisheries in Tanzania. Ambio: a journal of the Human Environment. 2002;31(7):518-527.

42. Wilkinson C. Status of Coral Reefs of the World. Australian Institute of Marine Science, Townsville, Australia. 2000. 376 p.

43. Wilkinson C. Status of Coral Reefs of the World. Australian Institute of Marine Science, Townsville. Australia. 2004. 557 p.

44. Wilkinson C. Status of Coral Reefs of the World. Townsville, Global Coral Reef Monitoring Network and Reef and Rainforest Research Centre. 2008. p. 1-304.

45. Muhando CA, Lanshammar F. Ecological Effects of the Crown of thorn Starfish Removal Programme on Chumbe Island Coral Park, Zanzibar, Tanzania. Proceedings of the $11^{\text {th }}$ International Coral Reef Symposium. 2008. p. 7-11.

46. Muhando CA, Onganda H, Bydekeke L. Physical alteration and Destruction of Habitats (PADH): Overview of Physical and Destruction of Habitats in the Eastern African Region using Geographical Information System (GIS). UNEP/GPA/WIOMSA Report. 2004. 87 p.

47. Sheikh MA, Juma FS, Staehr PA, et al. Occurrence and distribution of antifouling biocide Irgarol-1051 in coral reef ecosystems, Zanzibar. Marine pollution bulletin. 2016;109(1):586-590.

48. Wilkinson C. Status of coral reefs of the world. Australian Institute of Marine Sciences, Townsville. 1998. 184 p.

49. Mohammed SM, Muhando CA, Machano H. Coral Reef Degradation in Tanzania: Results of Monitoring. In: Linden O, Souter D, editors. Coral Reef Degradation in the Indian Ocean. Status Report, Kalmar: CORDIO. 2002. p 21-30.

50. Gullström M, Lundén B, Bodin M, et al. Assessment of changes in the seagrass-dominated submerged vegetation of tropical Chwaka Bay (Zanzibar) using satellite remote sensing. Estuarine, Coastal and Shelf Science. 2006;67(3):399-408.

51. Nordlund LM, Erlandsson J, Torre-Castro M, et al. Changes in an East African social-ecological seagrass system: invertebrate harvesting affecting species composition and local livelihood. Aquatic Living Resources. 2010;23(4):399-416.

52. Orth RJ, Carruthers TJB, Dennison WC, et al. A Global Crisis for Seagrass Ecosystems. Bio Science. 2006;56(12):987-996. 
53. de la Torre-Castro M, Rönnbäck P, Links between humans and seagrasses - an example from tropical East Africa. Ocean and Coastal Management. 2004;47(7-8):361-387.

54. Mangora MM, MwanShalli MS, Sheikh MA, et al. Impacts of climate change on mangroves and mangrove dependent communities in the Western Indian Ocean. Zanzibar component. Report from Institute of Marine Sciences, University of Dar es Salaam. 2014. 37 p.

55. Griffith AL. Working scheme for the mangroves of the Zanzibar Protectorate. The Government Printer, Zanzibar. 1950. 42 p.

56. Hatcher BG. Coral reef ecosystems: how much greater is the whole than the sum of the parts? Coral Reefs.1997;16:S77-S91.

57. Johnstone RW, Muhando CA, Francis J. The Status of the Coral Reefs of Zanzibar: One Example of a Regional Predicament. Ambio. 1998;27:700-707.
58. Kubicek A, Muhando CA, Reuter H. Simulations of Long-Term Community Dynamics in Coral Reefs - How Perturbations Shape Trajectories. PLoS. Comput Biol. 2012;8(11):e1002791.

59. Nygård, H, Oinonen S, Hällfors. Price vs.Value of marine monitoring. Frontiers in Marine Science. 2016;3:205.

60. Nordlund LM, Kloiber U, Carter E, et al. Chumbe Island Coral Park governance analysis. Marine Policy. 2013;41:110-117.

61. TCMP. Tanzania Coastal Tourism Situation Analysis. TCMP Working Document no 5057. 2001. $51 \mathrm{p}$. 